\title{
Valuable Information for Orthopedic and Neurosurgeons
}

\author{
Nelson Hendler* \\ Former assistant professor of neurosurgery, Johns Hopkins University School of Medicine, USA
}

Submission: July 12, 2017; Published: July 20, 2017

*Corresponding author: Nelson Hendler, Former assistant professor of neurosurgery, Johns Hopkins University School of Medicine, past president of American Academy of Pain Management, USA, Email: docnelse@aol.com

\section{Research}

Researchers from Johns Hopkins Hospital have published information which reports:

a. $\quad 40 \%-80 \%$ of chronic pain patients are misdiagnosed [1-5] Most are told they have sprains and strains when they actually have surgically correctable lesions $[1,2,5]$. For CRPS (RSD) $71 \%-80 \%$ of patients really have nerve entrapment, which responded to peripheral nerve decompression $[3,4]$.

b. Doctors order the wrong tests and don't spend enough time taking a careful history. A Wall Street Journal article quotes medical research which says the two leading causes of misdiagnosis are

i. Ordering the wrong diagnostic test (57\%) and

ii. Poor history taking (56\%) [6].

c. MRIs miss damaged discs $76 \%-78 \%$ of the time, and CTs miss bony lesions detected by 3D-CT $56 \%$ of the time $[7,8]$.

d. Once a thorough history is taken, and the proper tests are ordered, $50 \%-63 \%$ of patients, previously told there is nothing to be done to help them, require surgery to improve $[1,2,5]$.

Don Long, MD, PhD, former chairman of neurosurgery at Johns Hopkins Hospital reported about a group of 70 patients with neck pain and headache, who, after having normal MRI, CT and X-rays, had been told that nothing could be done to help their pain. These patients then received facet blocks, root blocks, 3D-CT, flexion-extension X-rays and provocative disco grams. As the results of these tests, $63 \%$ of the patients were determined to be candidates for surgery. Post operatively, $93 \%$ of the patients improved [5]

A team of physicians from Johns Hopkins Hospital developed an Internet based questionnaire, which duplicates a physician taking a careful and thorough history. When the patient finishes the questionnaire, in either English or Spanish, called the Diagnostic Paradigm, then within five minutes, diagnoses are generated, based on the answers to the questions, which have a 96\% correlation with diagnoses of Johns Hopkins Hospital doctors [9]. Then, based on the correct diagnosis, the Treatment Algorithm recommends the correct test to use. The efficacy of this technique has been documented by the ability of the Diagnostic Paradigm and Treatment Algorithm to predict intraoperative finding with $100 \%$ accuracy [10].

What is meant by the correct test? Since the MRI is not particularly accurate for diagnosing disc disease, other testing is needed. Please refer to the article by Dr. Long again. At Johns Hopkins Hospital the neurosurgeons used facet blocks, root blocks, provocative disco grams, and peripheral nerve blocks to improve the accuracy of diagnosis. These are interventional procedures, which require the use of a C-arm fluoroscope, and can be performed by an anesthesiologist, interventional radiologist, or a surgeon.

The tests are available at www.MarylandClinicalDiagnostics. com, and can increase income, and improve patient care.

These tests benefit the surgeon in various ways:

a) Produce a more accurate evaluation in less time, with less inter-rater reliability issues.

b) Get paid for the actual tests themselves, using CPT codes which have been used in the past. The average payment is $\$ 76$ for both tests.

c) See more patients in a day, since using the tests will allow a physician to evaluate a patient in 5 minutes instead of the normal 20-40 minutes.

d) The Treatment Algorithm will recommend that a physician perform facet blocks, root blocks, peripheral nerve blocks, and provocative disco grams at a far higher level than they do now. 
e) The number of patients who will require surgery will increase 50\%-63\%.

Orthopedic and neurosurgeons using the tests report an increase in income of at least $20 \%$ a year without increasing the time spent seeing patients, and produces better patient satisfaction.

\section{References}

1. Hendler NH, Kozikowski JG (1993) Overlooked physical diagnoses in chronic pain patients involved in litigation. Psychosomatics 34(6): 494-501.

2. Hendler N, Bergson C, Morrison C (1996) Overlooked physical diagnoses in chronic pain patients in litigation, Part 2. Psychosomatics 37(6): 509-517.

3. Hendler N (2002) Differential diagnosis of complex regional pain syndrome. Pan Arab Journal of Neurosurgery 6(2): 1-9.

4. Dellon AL, Andronian E, Rosson GD (2009) CRPS of the upper or lower extremity: surgical treatment outcomes. J Brachial Plex Peripher Nerve Inj 4(1): 1.
5. Long DM, Davis RF, Speed WG, Hendler NH (2006) Fusion for occult post-traumatic cervical facet injury. Neurosurgery Quarterly 16(3): 129-135.

6. Landro L (2013) The Wall Street Journal 17.

7. Sandhu HS, Sanchez-Caso LP, Parvataneni HK, Cammisa FP, Girardi FP, et al. (2000) Association between findings of provocative discography and vertebral endplate signal changes as seen on MRI. J Spinal Disord 13(5): 438-43.

8. Zinreich SJ, Long DM, Davis R, Quinn CB, McAfee PC, et al. (1990) Three-dimensional CT imaging in postsurgical "failed back" syndrome. J Comput Assist Tomogr 14(4): 574-580.

9. Hendler N, Berzoksky C, Davis RJ (2007) Comparison of Clinical Diagnoses Versus Computerized Test Diagnoses Using the Mensana Clinic Diagnostic Paradigm (Expert System) for Diagnosing Chronic Pain in the Neck, Back and Limbs. Pan Arab Journal of Neurosurgery, pp. 8-17.

10. Landi A, Davis R, Hendler N, Tailor A (2016) Diagnoses from an On-Line Expert System for Chronic Pain Confirmed by Intra-Operative Findings. Journal of Anesthesia \& Pain Medicine 1(1): 1-7.

\section{Your next submission with Juniper Publishers will reach you the below assets}

- Quality Editorial service

- Swift Peer Review

- Reprints availability

- E-prints Service

- Manuscript Podcast for convenient understanding

- Global attainment for your research

- Manuscript accessibility in different formats

( Pdf, E-pub, Full Text, Audio)

- Unceasing customer service

Track the below URL for one-step submission https://juniperpublishers.com/online-submission.php 